\title{
Hydropower affects fish trophic structure both downstream of the dam a and upstream of the reservoir
}

Correspondence:

Patrícia Santos Fráguas psfraguas@yahoo.com.br

Submitted July 30, 2020

Accepted January 22, 2021

by Rosemara Fugi

Epub March 31, 2021

\section{${ }^{\circ}$ Patrícia Santos Fráguas ${ }^{1}$ and ${ }^{(}$Paulo Santos Pompeu ${ }^{2}$}

Dams often cause drastic changes in freshwater environments and can compromise the quality and availability of food resources in rivers. This study aims to analyze the influence of a dam on the trophic structure of fish assemblages in lotic areas located both upstream and downstream of the Irapé Hydroelectric Power Plant. Fish sampling occurred before (2003 to 2005) and after (2011 to 2017) the impoundment, which began in 2006. The trophic structure and species composition before dam construction were similar upstream of the reservoir and downstream of the dam. After the building of the dam, both aspects of the assemblages changed along the lotic stretches - the upstream incurred an increase in biomass of detritivores and a decrease of piscivores and omnivores, while downstream went exactly the opposite, causing a differentiation between the two assemblages. Because lotic areas upstream of reservoirs are also impacted by river damming, efforts for impact mitigation should also focus on these areas.

Keywords: Feeding, Fish assemblage, Irapé, Jequitinhonha River, Trophic guild.
Online version ISSN 1982-0224

Print version ISSN 1679-6225

Neotrop. Ichthyol.

vol. 19, no. 1, Maringá 2021
1 Programa de Pós-Graduação em Ecologia Aplicada, Departamento de Ecologia e Conservação, Instituto de Ciências Naturais, Universidade Federal de Lavras, 37200-900 Lavras, MG, Brazil. psfraguas@yahoo.com.br (corresponding author).

2 Laboratório de Ecologia de Peixes, Departamento de Ecologia e Conservação, Instituto de Ciências Naturais, Universidade Federal de Lavras, 37200-900 Lavras, MG, Brazil. pompeu@ufla.br. 
Barragens causam mudanças drásticas em ambientes de água doce e podem comprometer a qualidade e a disponibilidade de recursos alimentares nos rios. Este estudo teve como objetivo analisar a influência de uma barragem na estrutura trófica da assembleia de peixes em áreas lóticas localizadas a montante e a jusante da usina hidrelétrica de Irapé. A amostragem de peixes ocorreu antes (2003 a 2005) e após (2011 a 2017) o fechamento das comportas, iniciado em 2006. A estrutura trófica e a composição das espécies antes da construção da barragem eram semelhantes a montante do reservatório e a jusante da barragem. Após a construção da barragem, ambos os aspectos das assembleias mudaram ao longo dos trechos lóticos - a montante ocorreu um aumento na biomassa de detritívoros e diminuição de piscívoros e onívoros, enquanto a jusante ocorreu exatamente o oposto, causando uma diferenciação entre as duas assembleias. Como as áreas lóticas a montante dos reservatórios também são impactadas por barramentos, esforços para mitigação de impactos também devem se concentrar nessas áreas.

Palavras-chave: Alimentação, Assembleia de peixes, Guilda trófica, Irapé, Rio Jequitinhonha.

\section{INTRODUCTION}

Feeding is a dynamic process and diet can change based on shifts in ecologic conditions. These changes can affect growth, survival, and demographics of assemblages, and therefore affect the transfer of energy across the systems (Brodeur et al., 2017). Therefore, understanding changes in the trophic structure of fish assemblages caused by human-induced alterations can help to better understand such impacts and aid in the development of conservation and management strategies for freshwater environments (Pompeu, Godinho, 2003; Braga et al., 2012; Lima et al., 2020; Loch et al., 2020). Since a large number of dams are under construction or planned in the near future (Zarfl et al., 2019), expanding hydropower is one of the main threats to fluvial ecosystems (Reid et al., 2019). Damming alters the trophic ecology of rivers by causing fragmentation, changing the natural flow regime, and creating new reservoirs.

Fragmentation affects the fundamental processes and functions of healthy rivers, altering the natural flow of energy and nutrients (Dudgeon et al., 2006; Nestler et al., 2012). Impoundments also affect the natural flow regime, which is a key driver of river ecology (Bunn, Arthington, 2002) by determining channel morphology, habitat diversity, and substrate stability (Power et al., 1995; Nilsson, Svedmark, 2002). Alterations in natural flow regime change the availability of basal resources (detritus and phytoplankton) that provide energy to support food webs (Angradi, 1994), eventually compromising the quality of food resources downstream (Baxter, 1977; Abujanra et al., 2009). Reservoir creation causes a drastic transformation from a lotic to lentic habitat, consequently changing the physical, chemical, and geomorphological characteristics of the area (Agostinho et al., 2007).

These modifications influence the distribution, abundance, and diversity of organisms within these ecosystems (Poff, Zimmerman, 2010) by selecting species with functional 
traits related to the new conditions (Agostinho et al., 2016). Rheophilic and migratory species are more likely to be negatively affected since they are often associated with rapidly flowing water and depend on the natural flow regime to complete their life cycles (Arantes et al., 2019). The changing conditions also affects the different feeding guilds in distinct ways.

Shortly after filling, the reservoir undergoes a trophic upsurge period, consisting of a high nutrient input resulting from the decomposition of inundated vegetation and increased primary production (Kimmel et al., 1990; Agostinho et al., 2016). Detritivores, omnivores, herbivores, and insectivores increase in abundance exploring these resources, which also leads to increased prey availability for piscivores (Agostinho et al., 2016; Arantes et al., 2019). Over time, the reservoir progresses to a phase of trophic depletion marked by low productivity. At this point, fish abundance in the reservoir tends to decrease as species adjust to the new environment (Agostinho et al., 2016). Diet and trophic structure shifts due to reservoir creation have also been frequently documented in the literature (Albrecht, Pellegrini-Caramaschi, 2003; Luz-Agostinho et al., 2006; Delariva et al., 2013; Pereira et al., 2016).

Although the reservoir area experiences the most pronounced changes after dam construction (Baxter, 1977), the trophic ecology upstream of the reservoir (Dias et al., 2020) and downstream of the dam (Power et al., 1996) can also be affected. Increases in piscivorous, decreases in detritivorous biomass (Mérona et al., 2001; Peressin et al., 2016), and an overall dominance of omnivores and generalist feeders (Gandini et al., 2012; Sá-Oliveira et al., 2015; Peressin et al., 2016) have been observed downstream of dams after construction. Upstream of the reservoir, although these stretches of river tend to be considered control areas in relation to changes caused by the dam, changes have also been reported, related to populations that could migrate from the reservoir (Dias et al., 2020).

Studies aiming to analyse and compare trophic responses of fish assemblages, both upstream and downstream dam construction, are scarce (e.g., Sá-Oliveira et al., 2015; Monaghan et al., 2020). Therefore, the aim of our study is to compare between the fish assemblage trophic structures located upstream of the reservoir and downstream of the dam, both before and after the construction of the highest hydropower plant in Brazil. We expected downstream changes to be more pronounced due to flow regulation effects, and predicted that such changes will be observed both in species substitution and in changes to their relative biomass.

\section{MATERIAL AND METHODS}

Study area. The Jequitinhonha River basin drains an area of approximately $70,315 \mathrm{~km}^{2}$ across the states of Minas Gerais and Bahia, Brazil. Mean annual rainfall averages around 600 to $1,600 \mathrm{~mm}$ and are irregularly distributed throughout the year, although rainfall mostly occurs between October and March (IBGE, 1997). The Jequitinhonha River rises into the Espinhaço mountain range and runs 1,086 km northeast into the Atlantic Ocean (Guerrero, 2009).

The Irapé Hydroelectric Plant started its operation in 2006, and is the tallest dam in Brazil with $205 \mathrm{~m}$ high (Cachapuz, 2006). The reservoir has an area of 142.95 
$\mathrm{km}^{2}$, an installed power capacity of $360 \mathrm{MW}$, and holds up to $595,488 \mathrm{~m}^{3}$ of water (Cachapuz, 2006). Four sampling points were placed: two in lotic stretches upstream and two downstream of the Irapé Hydroelectric Power Plant $\left(16^{\circ} 44^{\prime} \mathrm{S} 42^{\circ} 34^{\prime} \mathrm{W}\right)$ on the Jequitinhonha River (Fig. 1). Upstream of the reservoir, the hydrological patterns have remained the same after the hydropower construction, while downstream of the dam, the effects of the power plant on the natural flow regime were evident (Fig. 2).

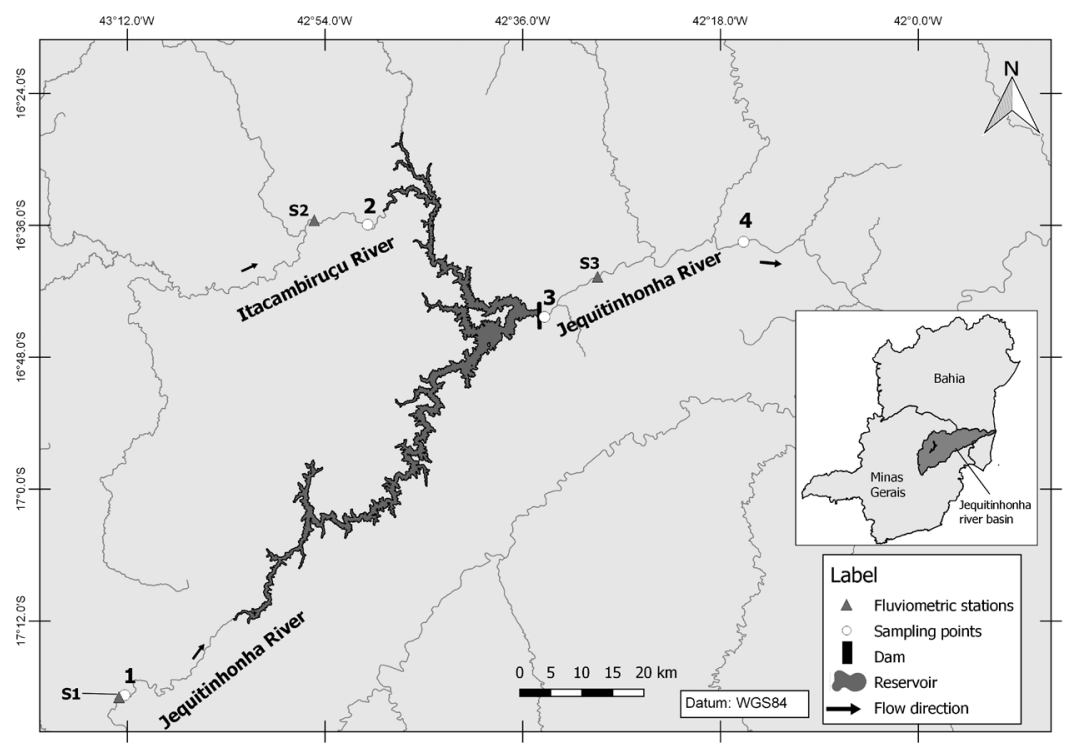

FIGURE 1 I Map of Irapé Hydroelectric Power Plant showing the fish sampling points (1 through 4) and fluviometric stations (S1, S2, S3).
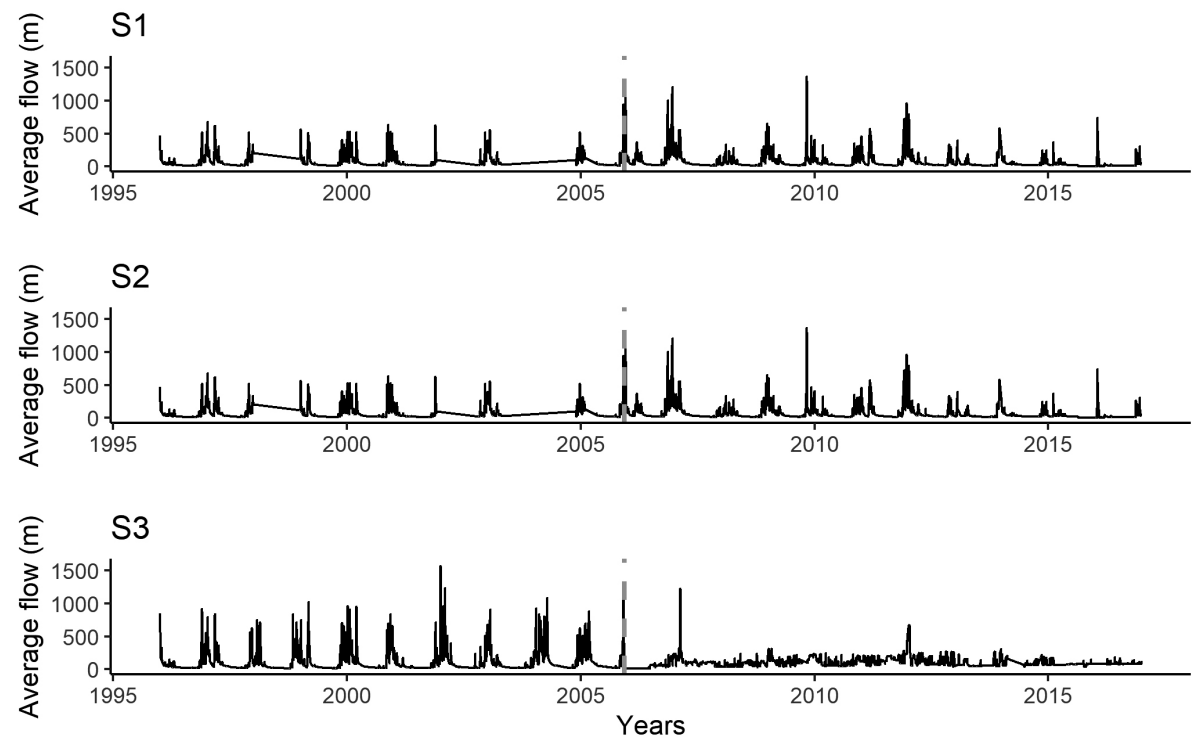

FIGURE 2 I Daily average flow for three fluviometric stations. S1 and S2 are located upstream of the reservoir, and S3 is located downstream of the dam. The gray dashed line represents the date in which the dam was closed. The Energy Company of Minas Gerais (CEMIG) provided historical flow data (1996 - 2016) of the fluviometric stations no 1743023 (S1), 1642029 (S2), and 1642044 (S3). 
Data sampling. Fish sampling occurred biannually both prior to the construction of the dam from 2003 to 2005, and after construction from 2011 to 2017 (Tab. 1), comprising both rainy and dry seasons. For fish collection, we used gillnets with mesh sizes 2.4, 3, 4, 5, 6, 7, 8, 10, 12, 14 and $16 \mathrm{~cm}$ between opposite knots. All net lengths were $30 \mathrm{~m}$, except for the 2.4 mesh net which was $20 \mathrm{~m}$ long. All nets were exposed for $12 \mathrm{~h}$ overnight. Fish were captured exclusively using gillnets. Almost all individuals were dead when nets were removed the next day, so euthanasia was unnecessary. We fixed the collected individuals in formaldehyde and preserved them in alcohol in the laboratory. Fish were identified with comparisons to collections in the Museu de Ciências Naturais (MCNIP) at the Pontifícia Universidade Católica de Minas Gerais. Specimens were deposited at the Ichthyological Collection of MCNIP under the catalog numbers: MCNIP 0348, 0333, 0340, 0346, 0050, 0347, 0049, 0336, 0184, and 0051.

In the laboratory, fish were measured, weighted, and had their stomachs removed for subsequent analysis. Under a stereomicroscope, stomach contents were analysed to the lowest possible taxonomic level. Identification of food items was made with the aid of a taxonomic bibliography (Ward, Whipple, 1918; Costa et al., 2006; Mugnai et al., 2010). The wet weight of the items was determined using a precision scale (Ohaus Adventurer, AR $2140-0,0001 \mathrm{~g})$.

Data Analysis. We classified the species into trophic guilds through a bibliographic review (S1) and stomach content analysis. For species without dietary descriptions in the literature, we analysed up to 10 stomachs. To determine the importance of each food item for each species, the food index (IAi) (Kawakami, Vazzoler, 1980) was calculated, but the volume of the items was replaced by their weight (Bennemann et al., 2006) as shown in the following formula:

$$
I A i=\frac{F i x P i}{\sum_{i=1}^{n}(F i x P i)} x 100
$$

where $\mathrm{IAi}=$ Alimentary Index, $\mathrm{Fi}=$ Frequency of occurrence $(\%)$ of food item $\mathrm{i}$, and $\mathrm{Pi}$ $=$ Weight $(\%)$ of food item $\mathrm{i}$. Based on the IAi, the consumption of $\geq 50 \%$ (Bennemann

TABLE 1 I Number of sampling for each fish sampling point before and after the construction of the dam.

\begin{tabular}{|c|c|c|c|}
\hline Period & Sampling point & Location & Number of samplings \\
\hline & 1 & $17^{\circ} 18^{\prime} 44.8^{\prime \prime} \mathrm{S} 43^{\circ} 12^{\prime} 14.9^{\prime \prime} \mathrm{W}$ & 6 \\
\hline Before & 2 & $16^{\circ} 35^{\prime} 56.4^{\prime \prime} \mathrm{S} 42^{\circ} 50^{\prime} 07.9^{\prime \prime} \mathrm{W}$ & 5 \\
\hline & 4 & $16^{\circ} 37^{\prime} 30.04 " \mathrm{~S} 42^{\circ} 15^{\prime} 54.58^{\prime \prime} \mathrm{W}$ & 7 \\
\hline & 1 & $17^{\circ} 18^{\prime} 44.8^{\prime \prime} \mathrm{S} 43^{\circ} 12^{\prime} 14.9^{\prime \prime} \mathrm{W}$ & 14 \\
\hline & 2 & $16^{\circ} 35^{\prime} 56.4{ }^{\prime \prime} \mathrm{S} 42^{\circ} 50^{\prime} 07.9^{\prime \prime} \mathrm{W}$ & 27 \\
\hline & 3 & $16^{\circ} 44^{\prime} 20.6^{\prime \prime} \mathrm{S} 42^{\circ} 34^{\prime} 02.3^{\prime \prime} \mathrm{W}$ & 11 \\
\hline
\end{tabular}


et al., 2011) of the same food item was used to classify the species in each guild (detritivore, herbivore, omnivore, piscivore, and insectivore). Species that consumed food items from animal and plant sources on similar proportions were classified as omnivores. When data of bibliographic review and IAi were available, we used whichever classification was based on a higher number of individuals. To determine trophic structure, we summed the biomass of the species individuals belonging to each guild.

To evaluate whether trophic structure changed with site (upstream and downstream) or with dam construction, the fish assemblages were compared considering four groups according to the location (upstream or downstream) and time (before or after) relative to the dam construction. Data was standardized by the total biomass in each sample. These groups were sorted by non-metric multidimensional scaling analysis (NMDS) (Legendre, Legendre, 2012) using the Bray-Curtis similarity index and compared by Analysis of Similarities (ANOSIM) (Clarke, 1993). The similarity percentage analysis (SIMPER) (Clarke, 1993) was used to evaluate which guild contributed most to the differentiation of these groups.

To assess the effects of location and damming on species composition and occurrence, we sorted groups of species by two NMDS analysis: one based on the biomass of each species using the Bray-Curtis similarity index and the other based on the presence/ absence of species using Jaccard similarity index. Then, we conducted ANOSIM between pairs of groups by location (before upstream $\mathrm{x}$ before downstream and after upstream $x$ after downstream) and period (before upstream $x$ after upstream and before downstream $x$ after downstream) to determine differences between those groups. The similarity percentage analysis was used to evaluate which species contributed most to the differentiation of these groups. All ANOSIM analyses were conducted with 999 permutations. NMDS, ANOSIM, and SIMPER tests were performed in Primer 6 using the PERMANOVA+ package (Clarke, Gorley, 2006).

\section{RESULTS}

Trophic structure. A total of 4,055 individuals belonging to 31 species were sampled. Sixteen species were recorded both before and after dam closure, while three species were captured only before dam construction and 12 only after. Regarding the feeding habits, 10 species were classified as detritivores, 2 as herbivores, 3 as insectivores, 10 as omnivores, and 6 as piscivores $(\mathbf{S} 1, \mathbf{S} 2)$.

Before the construction of the dam, there was no difference in the trophic structure between the river segments upstream and downstream. After the construction of the dam, however, the two regions differed from the previous state, and they also became different from each other (Fig. 3; Tab. 2).

After the dam implementation, the area sampled upstream experienced an increase in biomass of detritivores and a decrease of piscivores. Downstream, on the other hand, showed an exactly opposite response for these guilds, presenting an increase of omnivore biomass and causing a differentiation between the two assemblages (Fig. 3A; Tab. 3). Due to the sharp variations in biomass downstream after the dam construction, we performed the analysis without site 3 , which had the higher number of samples, to 

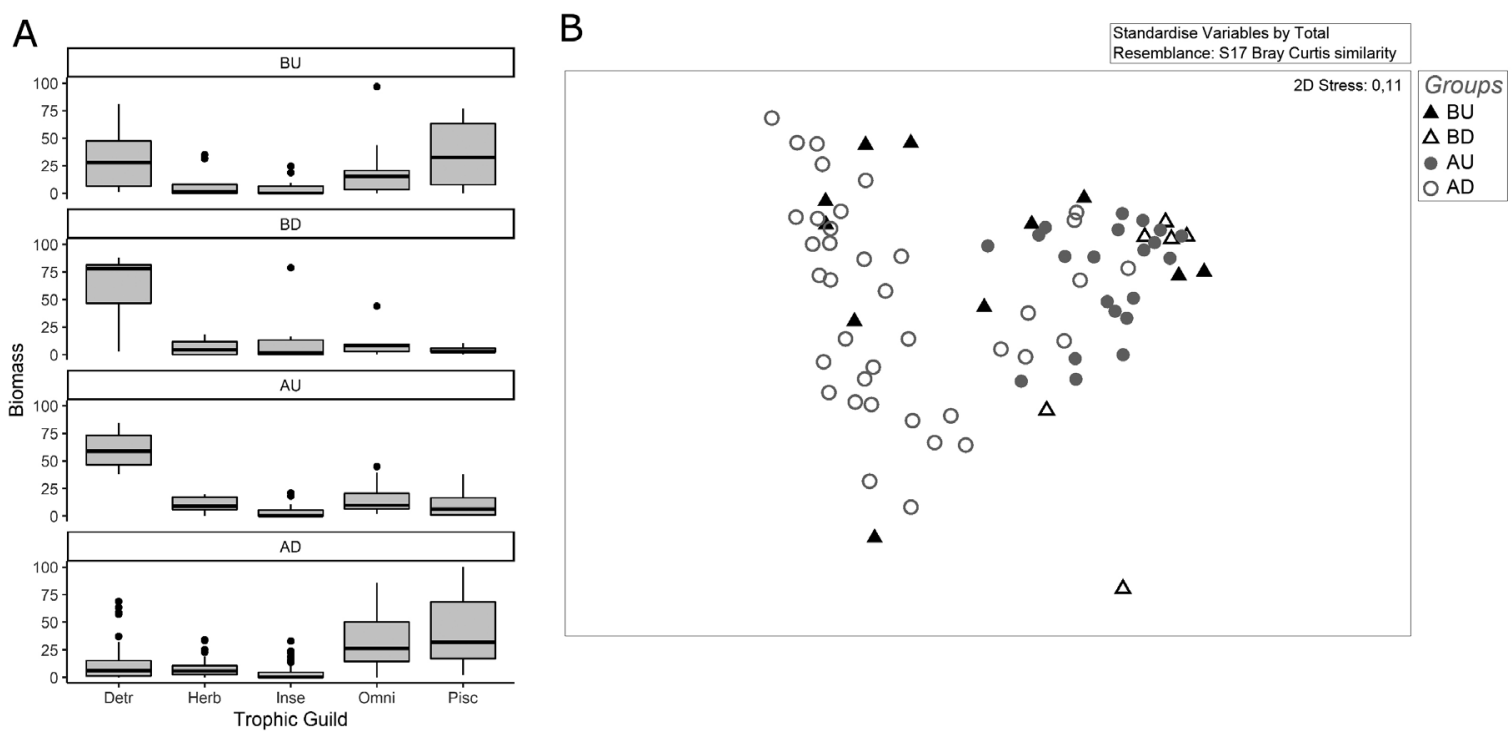

FIGURE 3 । A. Trophic structure of the fish assemblage represented by relative biomass of the trophic guilds. Line inside the box = median; box $=25^{\text {th }}$ and $75^{\text {th }}$ percentiles; whiskers $=1.5 \mathrm{x}$ IQR; dots $=$ outliers. B. Non-metrical multidimensional scaling (NMDS) of the relative biomass for each trophic guild. (Detr= Detritivores, Herb= Herbivores, Inse= Insectivores, Omni= Omnivore, Pisc= Piscivore, BU= Before/upstream, $\mathrm{BD}=$ Before/downstream, $\mathrm{AU}=$ After /upstream, $\mathrm{AD}=\mathrm{After} /$ downstream).

TABLE 2 I ANOSIM tests for trophic structure and species composition (BU= Before/upstream, BD= Before/downstream, AU= After / upstream, $\mathrm{AD}=\mathrm{After} /$ downstream). Level of significance $\mathrm{p}<0.05$.

\begin{tabular}{|c|c|c|c|c|c|c|}
\hline \multirow{2}{*}{ Groups } & \multicolumn{2}{|c|}{ Trophic Structure } & \multicolumn{4}{|c|}{ Species composition } \\
\hline & & & Species substitution & Relative biomass \\
\hline & R statistical & p value & R statistical & p value & R statistical \\
\hline BU, AU & 0.483 & 0.001 & 0.450 & 0.001 & 0.378 & 0.002 \\
\hline BD, AD & 0.615 & 0.001 & 0.482 & 0.004 & 0.547 & 0.39 \\
\hline AU, AD & 0.477 & 0.001 & 0.424 & 0.001 & 0.001 \\
\hline BU, BD & 0.139 & 0.102 & 0.013 & 0.402 & 0.077 \\
\hline
\end{tabular}

assess its impact on fish biomass. Analyses without site 3 followed the same tendencies of when it was included (S3).

Species composition. The observed trophic structure changes occurred due to both species composition and changes in relative biomass (Fig. 4; Tab. 2). After dam construction in the upstream region, the migratory detritivorous Prochilodus hartii Steindachner, 1875, increased its biomass while the sedentary predators from genus Hoplias Gill, 1903, had lower captures. Downstream of the dam, Prochilodus hartii decreased in biomass, while the omnivorous Wertheimeria maculata Steindachner, 1877, and native (Hoplias spp.) and the non-native (Serrasalmus brandtii Lütken, 1875) piscivorous increased (Tab. 4). 
TABLE 3 I Similarity percentage analysis of the trophic structure between the groups (BU= Before/upstream, BD= Before/downstream, AU= After/upstream, $\mathrm{AD}=$ After/downstream).

\begin{tabular}{|c|c|c|c|c|c|c|}
\hline \multirow{2}{*}{ Trophic Guilds } & \multicolumn{4}{|c|}{ Groups / Average biomass } & \multirow{2}{*}{$\begin{array}{c}\text { Contribution } \\
\%\end{array}$} & \multirow{2}{*}{$\begin{array}{c}\text { Cumulative } \\
\%\end{array}$} \\
\hline & $\begin{array}{c}\text { Before } \\
\text { Upstream }\end{array}$ & $\begin{array}{c}\text { Before } \\
\text { Downstream }\end{array}$ & $\begin{array}{c}\text { After } \\
\text { Upstream }\end{array}$ & $\begin{array}{c}\text { After } \\
\text { Downstream }\end{array}$ & & \\
\hline \multicolumn{7}{|l|}{ BU x AU Average dissimilarity = 53.39} \\
\hline Detritivore & 30.67 & & 59.97 & & 34.56 & 34.56 \\
\hline Piscivore & 35.9 & & 10.37 & & 29.82 & 64.38 \\
\hline Omnivore & 20.53 & & 14.77 & & 18.14 & 82.52 \\
\hline Herbivore & 7.8 & & 10.7 & & 11.02 & 93.54 \\
\hline \multicolumn{7}{|l|}{$\mathrm{BD} \times \mathrm{AD}$ Average dissimilarity $=71.33$} \\
\hline Detritivore & & 60.93 & & 13.9 & 36.38 & 36.38 \\
\hline Piscivore & & 4.21 & & 40.86 & 25.83 & 62.21 \\
\hline Omnivore & & 11.8 & & 32.62 & 19.3 & 81.51 \\
\hline Insectivore & & 16.43 & & 4.42 & 12.47 & 93.98 \\
\hline \multicolumn{7}{|l|}{ AU x AD Average dissimilarity $=60.50$} \\
\hline Detritivore & & & 59.97 & 13.9 & 39.38 & 39.38 \\
\hline Piscivore & & & 10.37 & 40.86 & 27.57 & 66.95 \\
\hline Omnivore & & & 14.77 & 32.62 & 20.33 & 87.29 \\
\hline Herbivore & & & 10.7 & 8.2 & 7.36 & 94.65 \\
\hline
\end{tabular}

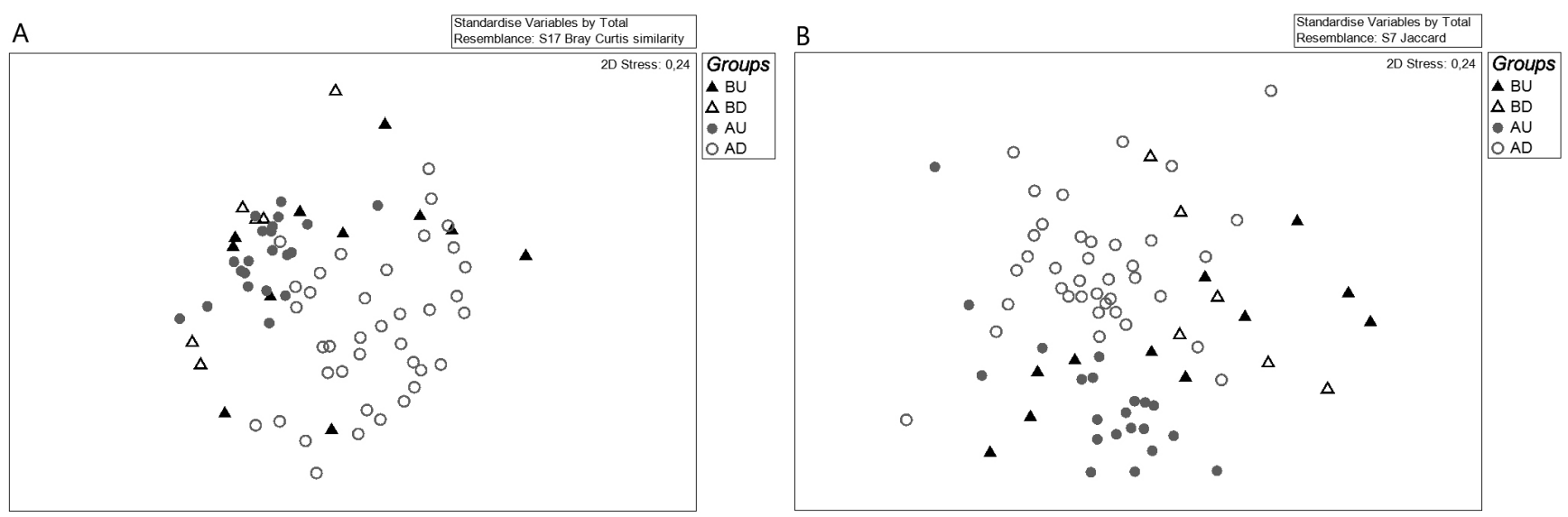

FIGURE 4 I A. Non-metrical multidimensional scaling (NMDS) of trophic structure. B. NMDS of species composition. (BU= Before/ upstream, $\mathrm{BD}=\mathrm{Before} /$ downstream, $\mathrm{AU}=\mathrm{After} /$ upstream, $\mathrm{AD}=\mathrm{After} /$ downstream).

TABLE 4 I Similarity percentage analysis of species composition between groups $(B U=$ Before/upstream, BD= Before/downstream, $A U=$ After/upstream, $\mathrm{AD}=$ After/downstream).

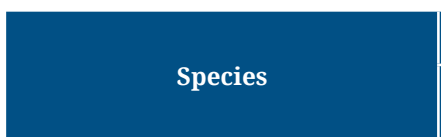

BU x AU Av.Diss = 73.09

Prochilodus hartii

Hoplias malabaricus

Hoplias brasiliensis

\begin{tabular}{|c|c|c|}
\hline & \multicolumn{2}{c}{ Groups / Average biomass } \\
\hline $\begin{array}{c}\text { Before } \\
\text { Upstream }\end{array}$ & $\begin{array}{c}\text { Before } \\
\text { Downstream }\end{array}$ & After Upstream \\
\hline
\end{tabular}

\begin{tabular}{|c|}
\hline After \\
Downstream
\end{tabular}

Co

Contribution $\%$

Cumulative

$\%$

19.19

19.19

29.8

13.54

4.43

10.62

39.22 
TABLE 4 । (Continued)

\begin{tabular}{|c|c|c|c|c|c|c|}
\hline \multirow[b]{2}{*}{ Species } & \multicolumn{4}{|c|}{ Groups / Average biomass } & \multirow[b]{2}{*}{ Contribution $\%$} & \multirow{2}{*}{$\begin{array}{c}\text { Cumulative } \\
\%\end{array}$} \\
\hline & $\begin{array}{c}\text { Before } \\
\text { Upstream }\end{array}$ & $\begin{array}{c}\text { Before } \\
\text { Downstream }\end{array}$ & After Upstream & $\begin{array}{c}\text { After } \\
\text { Downstream }\end{array}$ & & \\
\hline Hypostomus sp. & 12.68 & & 12.85 & & 8.73 & 47.94 \\
\hline Megaleporinus garmani & 7.22 & & 9.86 & & 7.76 & 55.7 \\
\hline Hypomasticus steindachneri & 10.68 & & 1.18 & & 7.67 & 63.37 \\
\hline Delturus brevis & 0 & & 8.14 & & 5.57 & 68.94 \\
\hline Psalidodon cf. fasciatus & 0.19 & & 7.45 & & 4.99 & 73.93 \\
\hline Pseudoplatystoma sp. & 6.99 & & 0 & & 4.78 & 78.71 \\
\hline Megaleporinus elongatus & 5.11 & & 3.56 & & 4.53 & 83.25 \\
\hline Wertheimeria maculata & 4.31 & & 0.49 & & 3.21 & 86.45 \\
\hline Trachelyopterus galeatus & 3.3 & & 2.04 & & 2.93 & 89.38 \\
\hline Pareiorhaphis sp. & 0 & & 3.24 & & 2.21 & 91.59 \\
\hline \multicolumn{7}{|l|}{ BD x AD Av.Diss = 87.12} \\
\hline Prochilodus hartii & & 29.36 & & 7.73 & 16.87 & 16.87 \\
\hline Wertheimeria maculata & & 0.93 & & 16.68 & 9.43 & 26.3 \\
\hline Gymnotus carapo & & 16.43 & & 0.06 & 9.43 & 35.73 \\
\hline Steindachnerina elegans & & 15.84 & & 0.17 & 9.06 & 44.79 \\
\hline Hypostomus sp. & & 15.73 & & 1.7 & 8.53 & 53.32 \\
\hline Hoplias brasiliensis & & 1.13 & & 14.22 & 8.1 & 61.42 \\
\hline Serrasalmus brandtii & & 0 & & 12.76 & 7.32 & 68.74 \\
\hline Hoplias malabaricus & & 2.91 & & 11.82 & 6.51 & 75.26 \\
\hline Trachelyopterus galeatus & & 8.92 & & 4.8 & 5.62 & 80.87 \\
\hline Astyanax brevirhinus & & 5.67 & & 4.14 & 3.78 & 84.66 \\
\hline Hypomasticus steindachneri & & 1.34 & & 4.42 & 2.8 & 87.46 \\
\hline Megaleporinus elongatus & & 0 & & 4.35 & 2.5 & 89.96 \\
\hline Megaleporinus garmani & & 0.96 & & 4.06 & 2.38 & 92.34 \\
\hline \multicolumn{7}{|l|}{ AU x AD Av.Diss = 80.47} \\
\hline Prochilodus hartii & & & 35.14 & 7.73 & 18.8 & 18.8 \\
\hline Wertheimeria maculata & & & 0.49 & 16.68 & 10.35 & 29.15 \\
\hline Hoplias brasiliensis & & & 4.48 & 14.22 & 9.26 & 38.41 \\
\hline Serrasalmus brandtii & & & 0.78 & 12.76 & 7.99 & 46.41 \\
\hline Hoplias malabaricus & & & 4.43 & 11.82 & 7.83 & 54.24 \\
\hline Hypostomus sp. & & & 12.85 & 1.7 & 7.53 & 61.77 \\
\hline Megaleporinus garmani & & & 9.86 & 4.06 & 5.12 & 66.89 \\
\hline Delturus brevis & & & 8.14 & 0 & 5.06 & 71.94 \\
\hline Psalidodon cf. fasciatus & & & 7.45 & 3.83 & 4.43 & 76.38 \\
\hline Megaleporinus elongatus & & & 3.56 & 4.35 & 3.79 & 80.17 \\
\hline Trachelyopterus galeatus & & & 2.04 & 4.8 & 3.27 & 83.43 \\
\hline Hypomasticus steindachneri & & & 1.18 & 4.42 & 3.04 & 86.47 \\
\hline Astyanax brevirhinus & & & 0.84 & 4.14 & 2.52 & 89 \\
\hline Pareiorhaphis sp. & & & 3.24 & 0 & 2.01 & 91.01 \\
\hline
\end{tabular}




\section{DISCUSSION}

Before the dam construction, trophic structure and species composition were similar between the regions upstream and downstream of the future hydropower plant. After the dam construction, however, both aspects of the assemblages changed. The two regions became distinct and changed when compared to the previous conditions. Downstream of the dam, three trophic groups were affected: piscivores and omnivores increased in biomass, and detritivores decreased. Upstream of the reservoir, detritivores increased their biomass while piscivores decreased. It is important to highlight that this study focused only on the lotic areas upstream the reservoir and downstream of the dam, and did not evaluate intraspecific changes in trophic guilds by comparisons of stomach content analyses before and after the impoundment. We focused on assessing the changes in fish assemblage structure regarding trophic groups.

The observed changes in trophic structure and species composition downstream of the Irapé dam can be linked to its impacts as a barrier, on the water quality, and on the natural flow regime. The blockage of migration routes can lead to the accumulation of fish downstream of dams (Mérona et al., 2001), increasing the availability of fish as a food resource (Mérona et al., 2001; Delariva et al., 2013; Peressin et al., 2016). Alterations in water level and transparency can also make fish more vulnerable to predation (Granzotti et al., 2018), favoring visual predators. We observed an increase in the relative biomass of piscivores following the construction, represented by Hoplias spp., and Serrasalmus brandtii, an invasive species to the Jequitinhonha River basin (Andrade et al., 2018). Besides belonging to the same feeding guild, these species use different strategies to obtain food, possibly avoiding the overlap of resource consumption. Serrasalmus brandtii presents mutilating piscivorous habits, feeding on fish scales, fins, and flesh (Pompeu, 1999; Alvim, Peret, 2004; Andrade et al., 2018) whereas Hoplias malabaricus (Bloch, 1794) is a specialist piscivore (Hahn, Fugi, 2008), swallowing whole prey (Peretti, Andrian, 2008). These species are sedentary and are capable of spawning multiple times throughout the year, and therefore do not depend on the natural flow regime to complete their life cycle (Prado et al., 2006; HonoratoSampaio et al., 2009).

Impacts imposed by dams on downstream areas extend to other biological communities as well, such as macroinvertebrates. Changes in their abundance and density have been related to both flow regulation (Lobera et al., 2017) and daily flow peaking (Tupinambás et al., 2014), with associated responses in fish diet (Gandini et al., 2014). Therefore, an increase of omnivores is expected, related to their generalist feeding habits by preying on a broad spectrum of food resources (Gerking, 1994) and using resources according to their availability in the river. High levels of omnivory have been reported for communities subject to environmental disturbances (Wootton, 2017), and the same pattern was found on post-impoundment stretches on the Paraná River that presented increased numbers of fish with generalist feeding habits (Oliveira et al., 2018). Downstream of the Irapé dam, the relative biomass of Wertheimeria maculata, which is an opportunistic feeder (Vono, Birindelli, 2007), showed a noteworthy increase.

Changes on the natural flow regime can negatively affect detritivore species (Abujanra et al., 2009), as the input of allochthonous resources downstream also 
decreases with flow regulation (Mor et al., 2018). Moreover, dams trap sediments and nutrients in the reservoir (Baxter, 1977; Roberto et al., 2009), decreasing turbidity and nutrient load and therefore modifying water quality downstream (Agostinho et al., 2008). The decrease of detritivore relative biomass downstream of the dam observed in our study was also found downstream of the Tucuruí Dam (Mérona et al., 2001), and detritus was found to be the lesser consumed food item on the river downstream of 12 hydroelectric power plants (Peressin et al., 2016). In our study, Prochilodus hartii, a detritivorous migratory species, showed reduced biomass downstream of the dam. The species have terminal mouth and protractible lips, which allow them to obtain detritus from the bottom and other substrates. Their diet is composed of finely divided detritus and mud (Fugi et al., 2001), and therefore can be highly impacted by the oligotrophication caused by the dam. The Irapé reservoir has a water residency time of 457 days (Rodrigues, 2009), and longer water residence times increase the oligotrophication process by increasing nutrient and sediment retention (Santos et al., 2020). Impoundments also affect the reproductive aspects of migratory species (Agostinho et al., 2004); on the Jequitinhonha River, the migration blockage has had a negative effect on the populations of P. hartii (Abdo et al., 2018), and it can also be pointed out as one of the factors for its decrease in population numbers.

Upstream of the reservoir, changes in the trophic structure were not expected due to changes in resource availability, but could be explained by interferences in migratory fish movements caused by the hydropower plant (Agostinho et al., 2016; Wu et al., 2019), or from fish displacements from the reservoir (Dias et al., 2020; Monaghan et al., 2020). Since the post-dam data was collected five years after the reservoir was filled, the first explanation seems to be the most plausible. The most remarkable change was an increase in biomass of $P$. hartti. If the breeding sites of $P$. hartii are located upstream, the barrier represented by the reservoir (Pelicice et al., 2015) could be confining most of the population to the upstream region. Because they are able to complete their life cycle upstream of the reservoir, the lower portion of those lotic segments may have been used as the main feeding site available for the species.

The construction of the Irapé Hydropower Plant has led to changes in the trophic structure of lotic river stretches, both upstream of the reservoir and downstream of the dam. Therefore, impoundments will cause drastic changes, not only in the reservoir but also in the adjacent lotic remnants that were not affected by the transition from lotic to lentic regimes. Species composition and biomass changed in both upstream and downstream river stretches, leading to changes in trophic structure. As such, we emphasize that upstream lotic areas must be used with caution as control areas to evaluate changes in downstream/reservoir areas since they may not represent the assemblages before the impact occurred. Understanding the most affected trophic groups along the lotic stretches adjacent to dams is useful to determine conservation strategies for fish fauna. Downstream of dams, the use of artificial seasonal flows to emulate natural variation and reduce the effects of flow regulation downstream could constitute an alternative to minimize some of the observed changes. Upstream of the reservoir, the maintenance of long free flowing river stretches is possibly the best alternative to maintain the fish fauna trophic structure near the original one. 


\section{ACKNOWLEDGMENTS}

This study was financed by Programa Peixe Vivo from Companhia Energética de Minas Gerais (CEMIG) - Geração e transmissão code: 4570015931 and was financed in part by the Coordenação de Aperfeiçoamento de Pessoal de Nível Superior (CAPES) - Finance Code: 32004010017P3. This paper was partially produced during the Scientific Publication in Ecology Course (PEC 533) on the postgraduate program of Applied Ecology on UFLA. The authors thank Francisco Andrade for funding acquisition and all the support during this study. Thanks to Carina Porto (UFLA) for the support on stomach content analysis. The authors thank Carla Ribas and Cynthia Oliveira for suggestions on the text, and Jessica Schulte for the English revision of the manuscript. PSP received a research fellowship from the CNPq (303548/2017-7).

\section{REFERENCES}

- Abdo TF, Marcon L, Bazzoli N. Downstream effects of a large reservoir on the reproductive activity of Prochilodus hartii (Pisces: Prochilodontidae). Anim Reprod Sci. 2018; 190:102-07. https://doi. org/10.1016/j.anireprosci.2018.01.013

- Abujanra F, Agostinho AA, Hahn NS. Effects of the flood regime on the body condition of fish of different trophic guilds in the Upper Paraná River floodplain, Brazil. Braz J Biol. 2009; 69(2 Suppl):469-79. https://doi.org/10.1590/ S1519-69842009000300003

- Agostinho AA, Gomes LC, Pelicice FM. Ecologia e Manejo de Recursos Pesqueiros em Reservatórios do Brasil. Maringá: Eduem; 2007.

- Agostinho AA, Gomes LC, Santos NCL, Ortega JCG, Pelicice FM. Fish assemblages in Neotropical reservoirs: Colonization patterns, impacts and management. Fish Res. 2016; 173:26-36. https://doi. org/10.1016/j.fishres.2015.04.006

- Agostinho AA, Gomes LC, Veríssimo S, Okada EK. Flood regime, dam regulation and fish in the Upper Paraná River: Effects on assemblage attributes, reproduction and recruitment. Rev Fish Biol Fisheries. 2004; 14(1):11-19. https://doi.org/10.1007/ s11160-004-3551-y

- Agostinho AA, Pelicice FM, Gomes LC. Dams and the fish fauna of the Neotropical region: impacts and management related to diversity and fisheries. Braz J Biol. 2008; 68(4 Suppl):1119-32. https://doi. org/10.1590/S1519-69842008000500019
- Albrecht MP, Pellegrini-Caramaschi E. Feeding ecology of Leporinus taeniofasciatus (Characiformes: Anostomidae) before and after installation of a hydroelectric plant in the upper rio Tocantins, Brazil Miriam. Neotrop Ichthyol. 2003; 1(1):53-60. https://doi. org/10.1590/S1679-62252003000100006

- Alvim MCC, Peret AC. Food resources sustaining the fish fauna in a section of the upper São Francisco River in Três Marias, MG, Brazil. Braz J Biol. 2004; 64(2):195-202. https://doi.org/10.1590/ S1519-69842004000200003

- Andrade FR, Silva LD, Guedes I, Santos AM, Pompeu PS. Non-native white piranhas graze preferentially on caudal fins from large netted fishes. Mar Freshw Res. 2018; 70(4):585-93. https://doi. org/10.1071/MF18202

- Angradi TR. Trophic linkages in the Lower Colorado River: multiple stable isotope evidence. J North Am Benthol Soc. 1994; 13(4):479-95. https://doi. org/10.2307/1467845

- Arantes CC, Fitzgerald DB, Hoeinghaus DJ, Winemiller KO. Impacts of hydroelectric dams on fishes and fisheries in tropical rivers through the lens of functional traits. Curr Opin Environ Sustain. 2019; 37:28-40. https://doi. org/10.1016/j.cosust.2019.04.009

- Baxter RM. Environmental effects of dams and impoundments. Annu Rev Ecol Syst. 1977; 8:255-83. 
- Bennemann ST, Casatti L, Oliveira DC. Alimentação de peixes: proposta para análise de itens registrados em conteúdos gástricos. Biota Neotrop. 2006; 6(2):1-8. https://doi.org/10.1590/S167606032006000200013

- Bennemann ST, Galves W, Capra LG. Recursos alimentares utilizados pelos peixes e estrutura trófica de quatro trechos no reservatório Capivara (Rio Paranapanema). Biota Neotrop. 2011; 11(1):63-71. https://doi.org/10.1590/S167606032011000100006

- Braga RR, Bornatowski H, Vitule JRS. Feeding ecology of fishes: an overview of worldwide publications. Rev Fish Biol Fisher. 2012; 22(4):915-29. https://doi. org/10.1007/s11160-012-9273-7

- Brodeur RD, Smith BE, McBride RS, Heintz R, Farley E. New perspectives on the feeding ecology and trophic dynamics of fishes. Environ Biol Fish. 2017; 100(4):293-97. https://doi.org/10.1007/ s10641-017-0594-1

- Bunn SE, Arthington AH. Basic principles and ecological consequences of altered flow regimes for aquatic biodiversity. Environ Manage. 2002; 30(4):492-507. https://doi.org/10.1007/s00267-002-2737-0

- Cachapuz PBB. Usinas da Cemig: a história da eletricidade em Minas e no Brasil, 1952-2005. Rio de Janeiro: Memória da Eletricidade; 2006.

- Clarke KR. Non-parametric multivariate analyses of changes in community structure. Aust J Ecol. 1993; 18(1):117-43. https://doi.org/10.1111/j.1442-9993.1993. tb00438.x

- Clarke KR, Gorley RN. PrimerV6UserManual 2006.

- Costa C, Ide S, Simonka CE. Insetos imaturos: metamorfose e identificação. Ribeirão Preto: Holos; 2006.

- Delariva RL, Hahn NS, Kashiwaqui EAL. Diet and trophic structure of the fish fauna in a subtropical ecosystem: Impoundment effects. Neotrop Ichthyol. 2013; 11(4):891904. https://doi.org/10.1590/S167962252013000400017

- Dias RM, Ortega JCG, Strictar L, Santos NCL, Gomes LC, Luz Agostinho KDG et al. Fish trophic guild responses to damming: Variations in abundance and biomass. River Res Appl. 2020; 36(3):43040. https://doi.org/10.1002/rra.3591
- Dudgeon D, Arthington AH, Gessner MO, Kawabata ZI, Knowler DJ, Lévêque C et al. Freshwater biodiversity: Importance, threats, status and conservation challenges. Biol Rev. 2006; 81(2):163-82. https://doi.org/10.1017/S1464793105006950

- Fugi R, Agostinho AA, Hahn NS. Trophic morphology of five benthic-feeding fish species of a tropical floodplain. Braz J Biol. 2001; 61(1):27-33. https://doi.org/10.1590/ s0034-71082001000100005

- Gandini CV, Boratto IA, Fagundes DC, Pompeu PS. Estudo da alimentação dos peixes no rio Grande à jusante da usina hidrelétrica de Itutinga, Minas Gerais, Brasil. Iheringia Série Zool. 2012; 102(1):56-61. https://doi.org/10.1590/S007347212012000100008

- Gandini CV, Sampaio FAC, Pompeu PS. Hydropeaking effects of on the diet of a Neotropical fish community. Neotrop Ichthyol. 2014; 12(4):795-802. https://doi. org/10.1590/1982-0224-20130151

- Gerking SD. Feeding Ecology of Fish. San Diego: Academic Press, Inc.; 1994.

- Granzotti RV, Miranda LE, Agostinho AA, Gomes LC. Downstream impacts of dams: shifts in benthic invertivorous fish assemblages. Aquat Sci. 2018; 80(3):1-14. https://doi.org/10.1007/s00027-018-0579-y

- Guerrero P. Vale do Jequitinhonha: a Região e seus Contrastes. Rev Discente Expressões Geográficas. 2009; 5:81-100.

- Hahn NS, Fugi R. Environmental Changes, Habitat Modifications and Feeding Ecology of Freshwater Fish. In: Cyrino JEP, Bureau DP, Kapoor BG, editors. Feed. Dig. Funct. Fishes. Boca Raton: 2008. p.574.

- Honorato-Sampaio K, Santos GB, Bazzoli N, Rizzo E. Observations on the seasonal breeding biology and fine structure of the egg surface in the white piranha Serrasalmus brandtii from the São Francisco River basin, Brazil. J Fish Biol. 2009; 75(7):1874-82. https://doi.org/10.1111/ j.1095-8649.2009.02422.x

- IBGE. Diagnóstico ambiental da bacia do rio Jequitinhonha: diretrizes gerais para a ordenação territorial. Salvador: 1997.

- Kawakami E, Vazzoler G. Método gráfico e estimativa de índice alimentar aplicado no estudo de alimentação de peixes. Bol Inst Oceanogr. 1980; 29(2):205-07. https://doi. org/10.1590/S0373-55241980000200043 
- Kimmel BL, Lind OT, Paulson LJ. Reservoir primary production. In: Thornton KW, Kimmel BL, Payne FE, editors. Reservoir Limnology: Ecological Perspectives. New York: John Wiley and Sons; 1990. p.133-94.

- Legendre P, Legendre L. Numerical Ecology. Third. Amsterdam: Elsevier; 2012.

- Lima MAL, Doria CR, Carvalho AR, Angelini R. Fisheries and trophic structure of a large tropical river under impoundment. Ecol Indic. 2020; 113:106162. https://doi.org/10.1016/j.ecolind.2020.106162

- Lobera G, Muñoz I, López-Tarazón JA, Vericat D, Batalla RJ. Effects of flow regulation on river bed dynamics and invertebrate communities in a Mediterranean river. Hydrobiologia. 2017; 784(1):283-304. https://doi.org/10.1007/ s10750-016-2884-6

- Loch JMH, Walters LJ, Cook GS. Recovering trophic structure through habitat restoration: A review. Food Webs. 2020; 25:e00162. https://doi.org/10.1016/j. fooweb.2020.e00162

- Luz-Agostinho KDG, Bini LM, Fugi R, Agostinho AA, Júlio Jr. HF. Food spectrum and trophic structure of the ichthyofauna of Corumbá reservoir, Paraná river Basin, Brazil. Neotrop Ichthyol. 2006; 4(1):61-68. https://doi.org/10.1590/S167962252006000100005

- Mérona B, Santos GM, Almeida RG. Short term effects of Tucurus Dam (Amazonia, Brazil) on the trophic organization of fish communities. Environ Biol Fish. 2001(60):375-92. https://doi. org/10.1023/A:1011033025706

- Monaghan KA, Agostinho CS, Pelicice FM, Soares AMVM. The impact of a hydroelectric dam on Neotropical fish communities: A spatio temporal analysis of the Trophic Upsurge Hypothesis. Ecol Freshw Fish. 2020; 29(2):384-97. https://doi. org/10.1111/eff.12522

- Mor JR, Ruhí A, Tornés E, Valcárcel H, Muñoz I, Sabater S. Dam regulation and riverine food-web structure in a Mediterranean river. Sci Total Environ. 2018; 625:301-10. https://doi.org/10.1016/j. scitotenv.2017.12.296

- Mugnai R, Nessimian JL, Baptista DF. Manual de identificação de macroinvertebrados aquáticos do Estado do Rio de Janeiro. $1^{\text {st }}$ ed. Rio de Janeiro: Techinal Books; 2010.
- Nestler JM, Pompeu PS, Goodwin RA, Smith DL, Silva LGM, Baigún CRM et $\boldsymbol{a l}$. The River Machine: A template for fish movement and habitat, fluvial geomorphology, fluid dynamics and biogeochemical cycling. River Res Appl. 2012; 28(4):490-503. https://doi.org/10.1002/ rra.1567

- Nilsson C, Svedmark M. Basic principles and ecological consequences of changing water regimes: Riparian plant communities. Environ Manage. 2002; 30(4):468-80. https://doi.org/10.1007/ s00267-002-2735-2

- Oliveira AG, Baumgartner MT, Gomes LC, Dias RM, Agostinho AA. Long-term effects of flow regulation by dams simplify fish functional diversity. Freshw Biol. 2018; 63(3):293-305. https://doi.org/10.1111/ fwb.13064

- Pelicice FM, Pompeu PS, Agostinho AA. Large reservoirs as ecological barriers to downstream movements of Neotropical migratory fish. Fish Fish. 2015; 16(4):697715. https://doi.org/10.1111/faf.12089

- Pereira LS, Agostinho AA, Delariva RL. Effects of river damming in Neotropical piscivorous and omnivorous fish: Feeding, body condition and abundances. Neotrop Ichthyol. 2016; 14(1):267-78. https://doi. org/10.1590/1982-0224-20150044

- Peressin A, Rodrigues RR, Godinho AL. Dieta e estrutura trófica da ictiofauna a jusante de usinas hidrelétricas da bacia do rio Paraná Superior. In: Loures RC, Godinho AL, (orgs.), editors. Avaliação Risco Morte Peixes em usinas Hidrelétricas, vol. 5. Série Peixe Vivo. Belo Horizonte: Companhia Energética de Minas Gerais; 2016. p.129-54.

- Peretti D, Andrian IF. Feeding and morphological analysis of the digestive tract of four species of fish (Astyanax altiparanae, Parauchenipterus galeatus, Serrasalmus marginatus and Hoplias aff. malabaricus) from the upper Paraná River floodplain, Brazil. Braz J Biol. 2008; 68(3):671-79. http://dx.doi.org/10.1590/ S1519-69842008000300027

- Poff NL, Zimmerman JKH. Ecological responses to altered flow regimes: a literature review to inform the science and management of environmental flows. Freshw Biol. 2010; 55(1):194-205. https:// doi.org/10.1111/j.1365-2427.2009.02272.x 
- Pompeu PDS. Dieta da pirambeba Serrasalmus brandtii Reinhardt (Teleostei, Characidae) em quatro lagoas marginais do rio São Francisco, Brasil. Rev Bras Zool. 1999; 16(supl 2):19-26. https://doi. org/10.1590/S0101-81751999000600003

- Pompeu PS, Godinho HP. Dieta e estrutura trófica das comunidades de peixes de três lagoas marginais do médio São Francisco. In: Godinho HP, Godinho AL, editors. Águas, peixes e pescadores do São Fr. das Minas Gerais. Belo Horizonte: Editora Puc Minas; 2003. p.183-94.

- Power ME, Sun A, Parker G, Dietrich WE, Wootton JT. Hydraulic Food-Chain Models: an approach to the study of food-web dynamics in large rivers. Bioscience. 1995; 45(3):159-67. https://doi. org/10.2307/1312555

- Power ME, Dietrich WE, Finlay JC. Dams and downstream aquatic biodiversity: Potential food web consequences of hydrologic and geomorphic change. Environ Manage. 1996; 20(6):887-95. https://doi.org/10.1007/BF01205969

- Prado CPA, Gomiero LM, Froehlich 0. Spawning and parental care in Hoplias malabaricus (Teleostei, Characiformes, Erythrinidae) in the southern Pantanal, Brazil. Braz J Biol. 2006; 66(2 B):697702. https://doi.org/10.1590/S151969842006000400013

- Reid AJ, Carlson AK, Creed IF, Eliason EJ, Gell PA, Johnson PTJ et al. Emerging threats and persistent conservation challenges for freshwater biodiversity. Biol Rev. 2019; 94(3):849-73. https://doi. org/10.1111/brv.12480

- Roberto MC, Santana NF, Thomaz SM. Limnology in the Upper Paraná River floodplain: large-scale spatial and temporal patterns, and the influence of reservoirs. Braz J Biol. 2009; 69(2 suppl):717-25. https://doi.org/10.1590/ s1519-69842009000300025

- Rodrigues RR. Sucesso reprodutivo de peixes migradores em rios barrados em Minas Gerais: influência da bacia de drenagem e das cheias. [Master Dissertation]. Belo Horizonte: Universidade Federal de Minas Gerais; 2009.
- Santos NCL, Dias RM, Alves DC, Melo BAR, Ganassin MJM, Gomes LC et al. Trophic and limnological changes in highly fragmented rivers predict the decreasing abundance of detritivorous fish. Ecol Indic. 2020; 110:105933. https://doi.org/10.1016/j. ecolind.2019.105933

- Sá-Oliveira JC, Hawes JE, Isaac-Nahum VJ, Peres CA. Upstream and downstream responses of fish assemblages to an eastern Amazonian hydroelectric dam. Freshw Biol. 2015; 60(10):2037-50. https://doi. org/10.1111/fwb.12628

- Tupinambás TH, Cortes RMV, Varandas SG, Hughes SJ, França JS, Callisto M. Taxonomy, metrics or traits? Assessing macroinvertebrate community responses to daily flow peaking in a highly regulated Brazilian river system. Ecohydrology. 2014; 7(2):828-42. https://doi.org/10.1002/ eco.1406

- Vono V, Birindelli JLO. Natural history of Wertheimeria maculata, a basal doradid catfish endemic to eastern Brazil (Siluriformes: Doradidae). Ichthyol Explor Freshwaters. 2007; 18(2):183-91.

- Ward H, Whipple G. Fresh-water biology. 2nd ed. New York: J. Wiley; 1918. https:// doi.org/10.5962/bhl.title.28152

- Wootton KL. Omnivory and stability in freshwater habitats: does theory match reality? Freshwater Biol. 2017; 62(5):82132. https://doi.org/10.1111/fwb.12908

- Wu H, Chen J, Xu J, Zeng G, Sang L, Liu Q et al. Effects of dam construction on biodiversity: a review. J Clean Prod. 2019; 221:480-89. https://doi.org/10.1016/j. jclepro.2019.03.001

- Zarfl C, Berlekamp J, He F, Jähnig SC, Darwall W, Tockner K. Future large hydropower dams impact global freshwater megafauna. Sci Rep. 2019; 9(1):18531. https://doi.org/10.1038/s41598019-54980-8 